\title{
The Social Media Use for Presidential Candidates Campaign and Political Awareness of Young Voters in Indonesia
}

\author{
Rajab Ritonga ${ }^{1}$, Marsetio ${ }^{2}$, Endah Murwani ${ }^{3}$, Bambang Nurochim ${ }^{2}$, Rudiyanto ${ }^{4}$, \\ Kazan Gunawan ${ }^{5}$ and Amarulla Octavian ${ }^{2}$ \\ ${ }^{1}$ Universitas Prof. Dr. Moestopo (Beragama), Jakarta, Indonesia \\ ${ }^{2}$ Indonesia Defense University, West Java, Indonesia \\ ${ }^{3}$ Universitas Multimedia Nusantara, Tangerang, Indonesia \\ ${ }^{4}$ Biro Klasifikasi Indonesia, Jakarta, Indonesia \\ ${ }^{5}$ Universitas Indonusa Esa Unggul, Jakarta, Indonesia \\ *Corresponding author: rajab.ritonga@dsn.moestopo.ac.id
}

\begin{abstract}
Social media accounts belonging to presidential candidates on the 2014 Indonesian Presidential Election are worthy of studying, particularly in terms of their users (the young voters); the question of which is whether they actively communicate via social media accounts owned by the presidential candidates and their supporters. In contrast, from the side of presidential candidates, what messages are communicated through their social media? This study was conducted with the survey method through questionnaire and content analysis on the accounts owned by presidential candidates of the Republic of Indonesia, and their interaction in the 2014 Presidential Election. The study results indicate that the respondents of young voters already have awareness on public issues related to the presidential candidates. This is reflected in the interest of respondents in noticing the social media accounts, such as Twitter and Facebook of Joko Widodo and Prabowo Subianto, and the accounts created by their supporters. The results of the analysis is that Prabowo, as one of the presidential candidates, managed directed messages in social media with a single line of command, and built a positive image, while the accounts belonging to Joko Widodo, another candidate, and those made by his supporters were not well coordinated.
\end{abstract}

Keywords: Political awareness; Presidential candidate campaign; Social media; Young voters

\section{Introduction}

The success of Barack Obama using social media in the US presidential electoral campaign in 2008 becomes the source of inspiration for political leaders around the world. Riaz [1] states that, "the Obama campaign was a revolution in new media technology and politics". Similarly, Macnamara [2] affirms that what Obama did is taking "political communication via social media to new heights". The phenomenon of the use of social media in the electoral campaigns is increasingly widespread when the successful use of social media in political campaigns also took place in many countries, including in Indonesia during the 2014 Presidential Election, between Joko Widodo-Jusuf Kalla and Prabowo Subianto-Hatta Rajasa.

A number of studies suggest that politicians in various countries have adopted social media to connect with constituents, directly communicate, and develop a political discussion, as demonstrated by Riaz in some African countries such as Ghana and

Received (March 15, 2017), Review Result (June 19, 2017), Accepted (August 19, 2017) 
Zimbabwe. The same thing happened in Argentina as stated by D'Adamoa [3], and in Germany, as presented by Faas [4] on a study entitled: "Bring the state (information) in: Campaign dynamics in the run-up to a German referendum". Social media is considered to be increasingly important for politicians because of its ability to create a space for dialogues between politicians and the public, and its potential to attract young voters. Beam et al., [5] studied the 2012 election in the United States to deepen the clicking vs. sharing: the relationship between online news behaviors and political knowledge. He tested the relationship between online news behaviors and political knowledge and stated that, "internet users show that reading online news is positively related to factual political knowledge".

Likewise, Momoc [6] who observed the election in Romania claimed that Facebook "(social media, generally speaking) seems to be a communication channel that will be used for sending political messages, once established that that is where the candidates' audience is". Social media, such as, Twitter, said Huberty [7], has been used as "new source of information for tracking and forecasting electoral contests in democratic societies" in the United States, Germany, and other democratic countries. Although according to Pennington et al., [8], users of social media such as Facebook, "was not related to following candidates on Facebook," social media becomes an important part in every election. Internet-based social media networks are increasingly considered to be significant and strategic for political communication in Indonesia, especially for the urban middle class. The ability of social media is considered effective in creating a space for dialogues between politicians and the public, and is expected to attract voters. A number of political parties have set up a special team to work on social media, including the preparation outreach in showing off the presidential candidates in the Election of 2014 [9]. Both pair of candidates for president-vice president understood the importance of using social media for a campaign [10].

The presidential candidate of the Republic of Indonesia, Prabowo Subianto even has made a Facebook and Twitter accounts since 2009, while Joko Widodo has made Twitter account since 2011 when he was still the mayor of Surakarta. In addition to the personal accounts of presidential candidates, there were various social media accounts affiliated with the presidential candidates, for example, @Jokowi4me, @PDI_Perjuangan, @Relawan_Jokowi, also @Jokowi4p presented to support Jokowi. While on the Prabowo's side, there were some accounts like @Gerindra, @FansGerindra, @GarudaPrabowo, and @GerindraDPDDKI.

The purposes of social media utilization for the presidential electoral campaign include: (1) to publish ideas, vision, mission, and programs of president-vice president candidates, done by the campaign team; (2) to multiply the news published by other parties beside the campaign team or by the campaign team, supporters and opponents; (3) to provide feedback on the news related to the election performed by the actors of social media individually or in groups. The target of social media utilization in the 2014 presidential electoral campaign is the middle-class urban young voters. Quantitatively, the population of Indonesian young citizens (15-40 years old) almost reached 40 percent of Indonesia's population, or 67 million, while the young voters or people who first used their voting rights (17-19 years old) reached 23 million people out of a total of $186,612,255$ registered in the Election Commission [11]. For young voters, social media is not only a medium of social interaction among them, but also serves as a means of political education. The question is whether the flow of political information received through social media can build political awareness of young voters. Moreover, some other political information supplies such as newspapers, radio, and television, are considered not neutral in providing information to the public.

By looking at these facts, there is actually huge potential for the nation's transformation in the future. Young people have to change the predicate as political object into political subject; this means that young people can play a major role in determining 
transformation in Indonesia. Then, how? Of course by encouraging and ensuring young people to participate and vote in the presidential election to choose candidates with integrity.

Through social media, political attitudes of young people can actually be formed. Social media can be used as a means of political learning in the 2014 election of president-vice president. The characteristics of social media that are independent, free and unlimited, enable young people to directly interact in recent political phenomenon.

The "babble" of young people in social media can be used as reference material in taking a political stance. A massive and continuous campaign in social media is expected to have an impact on the behavior of young voters in the presidential election. Through social media, young people can directly interact with the president-vice president candidates they want to vote. Certainly, this interaction can be in the form of opinion, advice, or even critical comment. Social media can be used as an alternative power that can provide equal opportunity to everyone to share and get news on a phenomenon that is happening. Everyone can express opinions, argues to provide correct information to others. From the aspect of any message conveyed, social media facilitates any forms of relationship apart from how communication is produced, reproduced, mediated, and accepted.

President-vice president candidates fought in the 2014 presidential election were notably aware of the importance of social media utilization. The social media like Twitter and Facebook were the choice for president-vice president candidates to communicate with their constituents, especially the youth as young voters. Even the presidential candidate, Prabowo, in his Twitter account believed that social media has a great influence. As for users of social networking in Indonesia, such as Twitter, based on data reported by Semiocast Dot Com, the number of the tweeps was 19.5 million people [12]. This number took the fifth place after the United States (about 107 million users), Brazil (33 million users), Japan (29 million users), and the UK (24 million users), while Jakarta is the city of most active tweet senders among other cities in the world, hence, it is not surprising that Indonesia often dominates the worldwide trending topic.

The phenomenon of the use of social media by the presidential candidates of the Republic of Indonesia and supporting political parties is worthy of studying, especially from the side of the social media users included in the category young of voters. The question is whether the young voters are interested to see the Twitter and Facebook accounts of the presidential candidates and their supporters. Then, are they interested to be a follower or friend of those accounts? Do they actively communicate through those Facebook and Twitter accounts of the presidential candidates? Instead, from the side of the presidential candidates and their supporters, what kinds of profiles and messages communicated via Twitter and Facebook accounts of the presidential candidates in order to get the interest of young voters to be involved in the interaction?

Broadly speaking, this study aims to determine (1) the level of political awareness of the social media users served as young voters in the Presidential Election 2014; (2) the messages conveyed by Prabowo and Joko Widodo as the presidential candidates, via their social media accounts, mainly Twitter and Facebook. In summary, the contributions of this study are as follow:

a. The mapping of the use of social media as a means of campaign in Indonesia Presidential Election 2014.

b. The mapping of the level of political awareness of young voters through social media involvement.

c. The mapping of campaign messages of presidential candidates through social media.

The rest of this paper is organized as follows: Section 2 discusses the matters related to social media and the election campaign; Section 3 describes the materials and methods; Section 4 presents the findings of the study, while the conclusion is given in Section 5. 


\section{Related Works}

\subsection{The Role of Social Media in Political Communication}

McQuail [13] states that social media is included in the category of collective participatory media whose users are easy to participate, collaborate, share ideas, information and experience, to develop friendship and build community. Meanwhile, Kaplan and Haenlein [14] classified social media into six types: (1) collaborative projects; (2) blogs and microblogs; (3) the content of the communities; (4) social networking sites; (5) virtual game worlds, and (6) social virtual worlds.

The function of social media is not just to share information; it can also be used as a revitalization of social relationship among users. Social media could be a place to virtually meet with friends, family or colleagues separated by the space and time. In addition, social media can be used as a media of self-presentation to form personal image, group, or organization image. The same thing was also expressed by McQuail that characteristic of new media is its force for creating image, publicity, and persuasion. According to McMillian [15], the characteristic of interactivity becomes important in the process of delivering messages on the internet because it creates the idea of two-way communication that occurs between the sender and the recipient of the message. Through social media, political parties and politicians as political actors need to pay attention to the image that will be built. Therefore, Kelley [16] stated that a clear identity will be the difference, such as the logo, name, symbol, or slogan. The use of media as identity must include a strong creative side, capable of delivering in-depth and interactive information, capable to embrace and be close to the audience, and the message can be received in various ways.

The up to date social media management and consistent communication continuity by using conversational structure that is developing in society determines the process of creating image through social media. Besides, politicians also encounter other challenges related to the use of social media as an attempt to show personal image formation in accordance with the expectations of society [17].

\subsection{Political Awareness and Involvement}

According to Hutchinson [18], political awareness can be divided into five categories. First, the illiterate-that is someone who is politically illiterate. They do not read at all and do not follow the news or political issues either from the media or from their environment. Second, the misinformed-people who have been attached emotionally, a movement, or charismatic personality. They are often dogmatic about their views and prefer the partisan rancor, as they will lose an objective debate. People in this category will usually claim to choose but frequently not. Third is known as the general. Fourth, the activist-someone who has a good understanding on the issues; which means that they can read the details of a section in each party and have worked at least in an election. Fifth, the expert-someone who understands the language of diplomacy and capable to build strategies with agencies and civil organizations. They always participate as voters in each election.

\section{Material and Methodology}

This study is a descriptive research to obtain a detailed description of; (1) the level of political awareness of the social media users who are young voters in the 2014 presidential election; (2) profiles and messages of presidential candidates, Prabowo Subianto and Joko Widodo through social media accounts; Twitter and Facebook owned by both presidential candidates. The population in this study is the social media users; Twitter and Facebook users who are registered for the first time as voters in the Presidential Election 2014, in this case, the students. The sampling technique is purposive 
with the number of respondents as many as 164 people. The data collection was done by using questionnaires distributed through google.com. As for scrutinizing the contents of conversations conducted by Prabowo Subianto and Joko Widodo through their Twitter and Facebook accounts, the content analysis is applied. The data collection from Twitter and Facebook accounts owned by both Indonesian presidential candidates was done during the presidential election campaign until Juli 9, 2014.

\section{Results and Discussion}

\subsection{The Social Media of Prabowo Subianto and His Supporters}

Prabowo Subianto, a presidential candidate supported by the party calling themselves Koalisi Merah Putih, has Twitter and Facebook accounts. His Twitter account is @ prabowo08. This account was made in May 17, 2009 just before the Election of 2009. At that time, Prabowo was the vice president candidate paired with Megawati from Partai Demokrasi Indonesia Perjuangan (PDIP).

The account @prabowo08 has 2,022,148 followers and follows 2,020 accounts (See Figures 1 and 2). The followers of @ prabowo08 was getting higher compared to the time before the legislative election accounted for less than one million. Until the data was collected in July 31, 2014, Prabowo has been tweeting as much as 8,227 times.

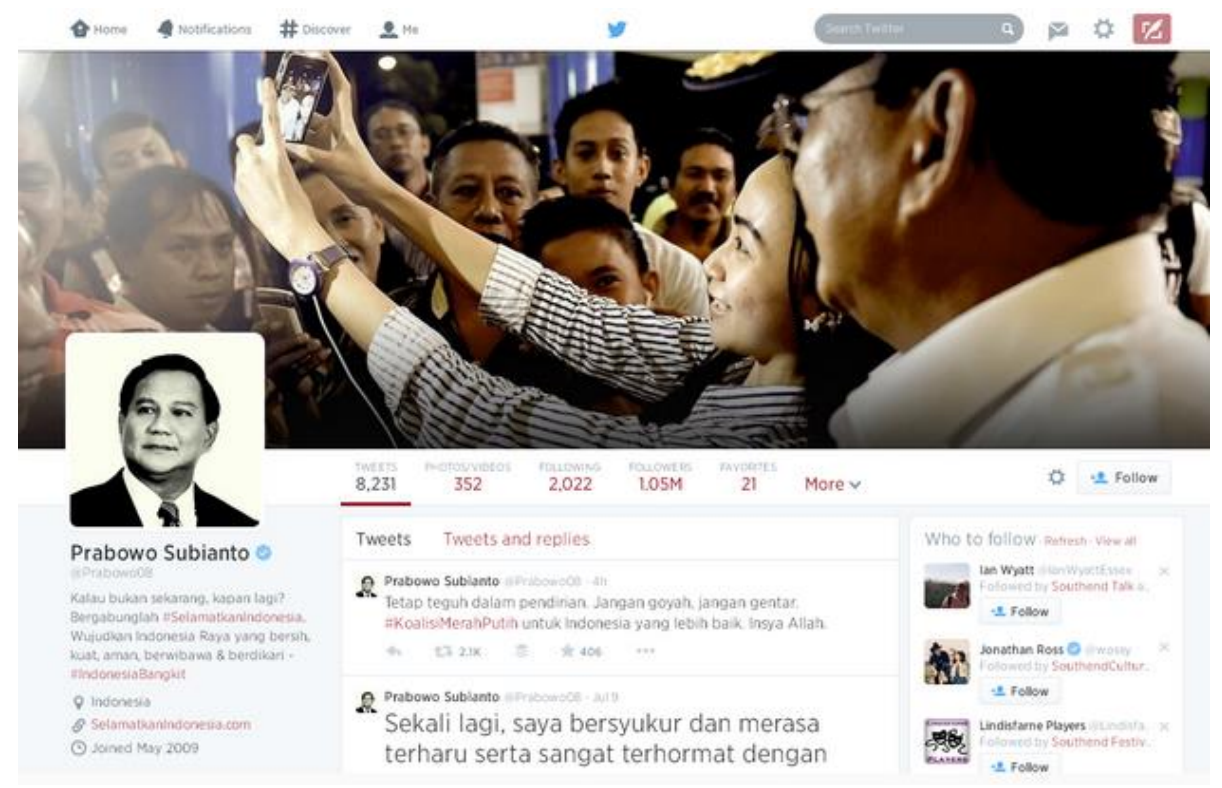

Figure 1. Prabowo's Twitter

Prabowo's profile shows his close-up photo with bio or self-description as follows: "Let us together defend the 1945 Constitution, defend the integrity of the Republic of Indonesia, and build the nation's Bhineka Tunggal Ika that is peaceful, strong, equitable, and prosperous".

Prabowo Subianto's background profile is the photos of his fans who was doing 'selfie' with Prabowo.

Prabowo Subianto via @prabowo08 actively interacted with his followers, he even greeted his followers with the term 'sahabat Twitter (Twitter's friends)'. During the presidential election campaign, his tweets were more likely to ask for prayers and support in the presidential debate on TV, asked his Twitter's friends to disseminate reasons to choose him. 
election, July 9, 2014, Prabowo updated his status saying, "Bismillahirrahmanirrahim" liked by as many as 878,122 , commented by 114,973 and shared by 5,334 people.

Twitter and Facebook accounts created by Prabowo's supporters include@Gerindra, @FansGerindra, and @GarudaPrabowo. The accounts of Prabowo's supporters tend to be few and limited, not as many as those made by Jokowi's supporters. However, the accounts created by Prabowo's supporters were neatly affiliated and clear, with directed line of command. It also made it easier to ward off negative and black campaigns made by the other parties against Prabowo Subianto.

\subsection{The Social Media of Joko Widodo and His Supporters}

Joko Widodo, as the second (number two) presidential candidate of the Republic of Indonesia, had two social media accounts, Twitter and Facebook accounts. His Twitter named @jokowi_do2 was made in September 3, 2011 with as many as 2,668,991 followers without following any account (See Figures 3 and 4). The account @Jokowi_do2 counted until July 31, 2014 had been tweeting for 933 times. His bio or self-description written in the account is, "Want to be simple in simplicity". His background picture was the cartoon of Jokowi and Jusuf Kalla.

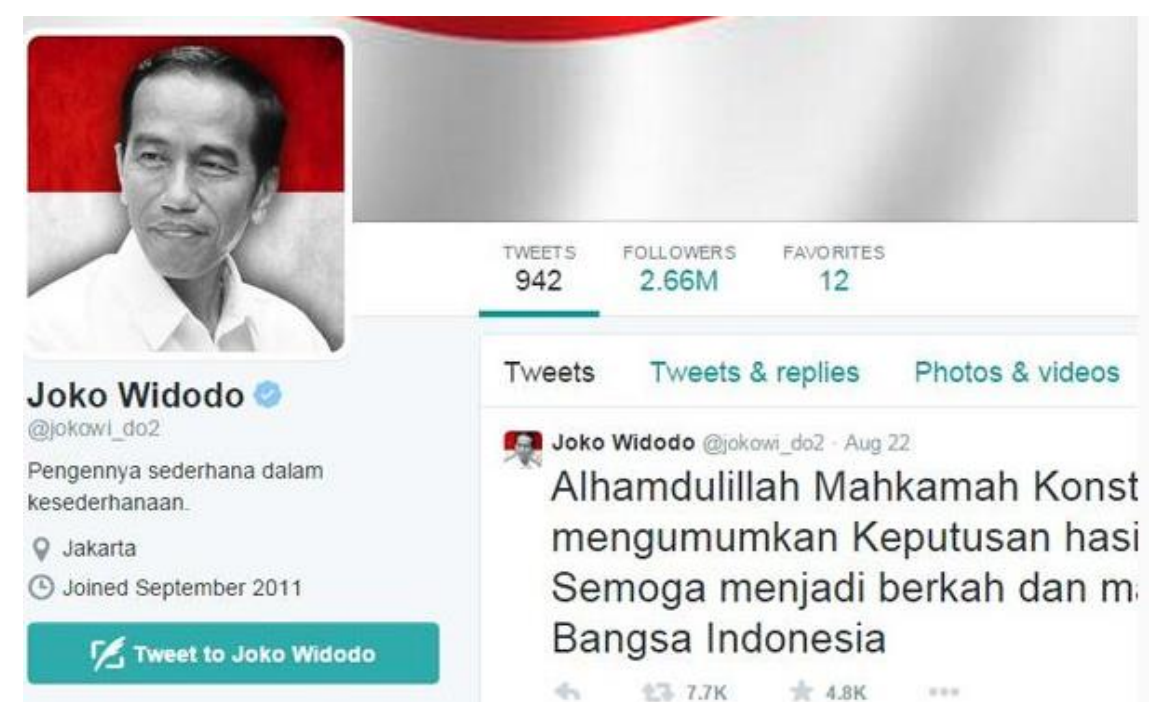

Figure 3. Joko Widodo's Tweeter

The Twitter account @ jokowi_do2 tended to rarely tweet compared to the presidential candidate number one, Prabowo Subianto. In particular, Jokowi also did not greet his followers with a specific name. Whenever he tweeted, Jokowi was immediately responded with retweets (RT) of his followers and his tweets were considered as favorites. During the period of the presidential campaign, @ jokowi_do2 just tweeted 39 times. The topics in Joko Widodo's timeline were about the presidential debate, his blusukan (visiting the field/citizens) style to get closer to the people, his campaign activities to many areas, and more likely to provide motivation, encouragement, and optimism to his volunteers.

The tweet by @jokowi_do2 in July 8, 2014, one day before the presidential election was "It's time for Indonesia people to change. See you in the polling station. May Allah SWT be with us. Warm regards from both of us \#Jokowi9Juli". The tweet written in July 9 after the voting day was, "Alhamdulilah, the presidential election was successful and encouraging, we will still guard the calculation in order to keep its transparency. Thank you our Indonesians folks".

When the results of the official count of KPU (Election Commision) set in July 22, 2014,@jokowi_do2 tweeted, “Thank God, thank you Indonesian folks. Let's forget 
Number 1, forget Number 2, put the unity first. Heavy task await us". This tweet of Joko Widodo was Retweeted (RT) 26,545 times and 5,483 times made as favorites. The Twitter account @jokowi_do2 seemed to be not managed by the campaign team of Joko Widodo, yet it was a personal account. This could be seen from the tweets that contain the characteristics of Jokowi.

Whereas, Joko Widodo's Facebook account was made in a fan-page named Jokowi with its profile cover of a picture in the form of Joko Widodo and Jusuf Kalla cartoon photo, completed with the background of a coast. His Facebook profile cover was as the same as his Twitter cover picture.

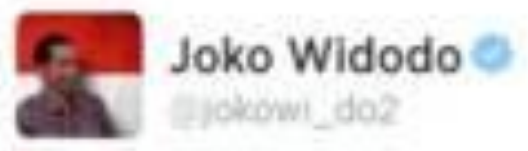

\section{Ini saatnya Bangsa Indonesia berubah. Sampai ketemu di TPS. Allah SWT beserta kita. Salam hormat kami berdua. \#Jokowi9Juli}

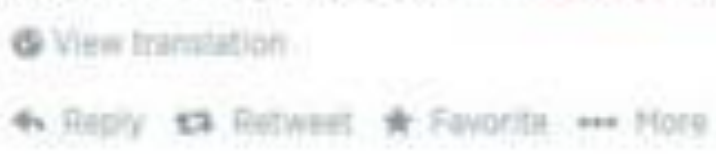

Figure 4. Joko Widodo's Twitter

The self-description, as well as his bio on his Twitter account, stated that, "It is my personal Facebook page that always seeks to be simple in simplicity". Until these data were collected in July 31, 2014, the statuses written on his Facebook account told the activities carried out by Joko Widodo after designated as a presidential candidate. To begin his leave as the Governor of DKI Jakarta, Joko Widodo uploaded the picture of his office that would be left until the end of voting activity. Activities undertaken during the campaign period dominated his Facebook status including his visit to Papua, which was written in the status, "Notes of The First Day in Papua, West Java, Cirebon, Central Java, Palembang, Jambi".

The vision, mission, and programs of Joko Widodo were also written in his Facebook status as the status posted in May 31, 2014, "Corruption is a parasite in this country. This is my vision and mission to eradicate corruption". The status of Joko Widodo in June 11, 2014, was, "I want to restore the glory of Indonesia as the Maritime State through Indonesian Maritime Restoration Program”. Joko Widodo's style of visiting the citizens in the field was said in his status in June 18 as the "energy that can always hear the aspirations of the people directly".

Joko Widodo's astonishment to a great music concert called "Salam Dua Jari" (regards two fingers) was revealed in his Facebook status in July 6, 2014: "During the presidential election campaign, every day was an unbelievable day for both of us and the climax was yesterday's afternoon at Gelora Bung Karno. I was amazed and really amazed to see Jokowi-JK supporters, who volunteered to come in droves to the concert of Salam Dua Jari event. It was an encouraging democratic party.

In addition, many Facebook accounts made by Joko Widodo's supporters, such as Jokowi Presiden, Jokowi, Rakyat Pendukung Joko Widodo, Seknas Jokowi, Jokowi-JK, 
Jokowi for Indonesia, Jokowi Blusukan, Bara Jokowi Presiden, Jokowi Mania, Presidenku Jokowi, Kawan Jokowi, Koordinator Nasional Relawan Jokowi, Relawan Pendukung Jokowi, We Love Jokowi.

The accounts made by Joko Widodo's supporters were widespread uncoordinatedly, thus the messages were not directed and one voice. These accounts often become the target to attack Joko Widodo with negative and black campaigns like the horrendous issues in social media, for example, RIP Joko Widodo, Mr. Joko Widodo is from Singapore, Jewish Agency, Corruptor, (member of) the Communist Party of Indonesia (PKI), and etc. In his status updated in July 2, 2014, Joko Widodo wrote, "Alamdulillah... We can prove that negative campaigns and black campaigns have proven to be wrong".

\subsection{Respondents' Political Awareness through the Presidential Candidates' Social Media Engagement}

Respondents in this study were amounted to 164 people who for the first time used their rights as voters the in presidential election 2014. All respondents said that they had more than one social media accounts, particularly Twitter. The accounts they had namely, Twitter, Facebook, Path, Line and Instagram.

For Twitter, 62.5 percent of respondents already had had a Twitter account for 3-4 years, even 18.75 percent of respondents claimed to have had a Twitter account for more than four years. Moreover, deeper observation on the activity of Twitter users, most respondents (83.33 percent) were classified as an active Twitter user. Similarly, for Facebook, 70 percent of respondents already had had a Facebook account since 3-4 years ago; however, its use was not as often as Twitter.

Then, were the respondents interested to see Twitter and Facebook accounts owned by the presidential candidate, Prabowo and Joko Widodo? The study findings show that 68.75 percent of total respondents claimed to have seen the Twitter accounts of Joko Widodo or Prabowo, although the majority of respondents claimed not to be their followers. Although the account @Prabowo08 was made earlier than @Jokowi_do2 account, Joko Widodo's popularity in social media influenced the respondents to see his Twitter account.

The study results also indicate that the frequency of respondents in checking Prabowo's or Joko Widodo's Twitter accounts and accounts created by the supporters tends to be low. Respondents actually saw the Twitter account whose issue was a trending topic, including the hash tag created by Sherina \#AkhirnyaMilihJokowi.

The study results show that of the total respondents, 25 percent is the followers of Jokowi's account and 6.25 percent is Prabowo's followers. For those respondents who became the followers of Joko Widodo's Twitter account said that Joko Widodo's tweets were relatable, informal, and sometimes hilarious.

However, after becoming the Governor of DKI Jakarta, Joko Widodo seldom tweeted. In contrast, the followers of Prabowo's Twitter account said that the reason for being a follower was due to their admiration and Prabowo's dignity. However, respondents said that the tweets posted on Prabowo's Twitter were less attractive because they only informed the positive things regarding the activities carried out by the candidate, his tweets were not in accordance with the information needed.

While the accounts created by Joko Widodo's supporters, like@Jokowi4me, @Relawan_Jokowi, @ Jokowi4p were seen by the respondents when there was an interesting issue related to a black campaign. The respondents's reason to see the twitter accounts created by Prabowo's supporters were to get up-to-date with talks on the issues regarding the presidential candidates, to compare information obtained from the official accounts with the accounts created by the candidates' supporters.

Regarding the frequency of ReTweet (RT), the results showed that there were some respondents who had retweeted the accounts of Joko Widodo and Prabowo Subianto. However, the frequency of respondents ReTweeting the accounts of Joko Widodo and 
Prabowo could be defined as rare. The analysis shows that Joko Widodo's tweets were frequently ReTweeted, even a tweet posted in July 22, 2014 was the highest record of ReTweet which was nearly 26,545 times, almost three times of Joko Widodo's ReTweets in July 9, 2014.

Similarly, for the accounts made by the supporters of both candidates, the study findings indicate that respondents rarely Re-Tweeted. When did the respondents retweet the accounts of the candidates or their supporters? Some of the respondents' answer were when dealing with inspiring tweets, when posting a tweet quoted by respondents, if the tweet provided motivation, if tweets did not always blame or do scapegoat the others, if respondents agreed with the tweet, or when the quote was nice.

As for Jokowi's Facebook, the findings show that the majority of respondents stated that they checked Joko Widodo's fan-page. However, they were confused because they did not know which account was official, for there were a lot of Facebook accounts made by Jokowi's supporters and volunteers, including, Jokowi Presidenku (Jokowi my President), Jokowi for Presiden 2014, Jokowi-JK, Jokowidodo Pilihan Rakyat (Jokowidodo the people's choice), Jokowi For President 2014. Otherwise, Prabowo's Facebook account was better known by the respondents since the accounts made by his supporters were not as many as the those created by Jokowi's supporters.

The study findings show that most respondents admitted that there was less awareness regarding the visions, missions, and programs offered by Jokowi and Prabowo through social media. Respondents were even more aware of the negative issues that attacked the candidates. The respondents' desire to be familiar with the negative issues of the candidates was increasing, which could raise or otherwise, decrease the respondents' preference to vote.

Broadly speaking, the study results, viewed from the social media accounts of Prabowo and Joko Widodo, show that the use of social media, especially Twitter and Facebook contains potentials. This is reflected by all respondents who already had Twitter and Facebook accounts; moreover, the majority of respondents had had an account since 3-4 years ago with fairly intense frequency of use.

However, the study findings indicate that young voters were more likely to use Twitter for personal talks among them. Otherwise, Facebook has begun to be abandoned by young people. Moreover, Twitter can upload photos though there is a limitation. Whereas, one of the conditions of social media is that it can influence the political process if the talks in social media lead to public issues.

The study results show that Joko Widodo's Twitter was more viewed and followed by the respondents, compared to the account owned by Prabowo. These findings need to be a concern of the politicians about how to communicate through social media, especially Twitter. Several matters that should be highlighted from this study include the introduction of the characters of Twitter users should be the consideration in the interaction of politicians with Twitter users.

Although Prabowo's twitter tried to be closer and acceptable to Twitter, the users who are mostly young people; that is by using the term 'friend (sahabat)' referred to the Twitter users, the content and style of his speech was formal and tended to be one-way.

Characteristics of interactive social media have not been used optimally; this can be seen from the few numbers of ReTweet (RT), mentions and favorites. Particularly, Joko Widodo, although he did not use certain term for his greeting, the activity and responses of his followers were quite high. This can be seen from the amount of RT or favorites every time Joko Widodo posted a tweet. Although the current range of Twitter is very limited, and it is mostly used by young people in urban areas, Twitter is potential to influence young voters. Communication that was supposed to be used between a presidential candidate with his followers was more personal and interactive. 
The Facebook used by the president-vice president candidates was in the form of a fanpage, limited only to convey president election information could be addressed and commented by friends, but the account owner could not comment and respond them.

Facebook in Indonesia that is accessible in many areas would be more effective to convey the information of the Presidential Election. The talks about the presidential election occurring in Facebook, and young voters had started to leave Facebook and more likely to use Twitter.

\section{Conclusion}

The first conclusion taken from the study findings is that the respondents who are young voters have already had awareness of public issues in accordance with the Presidential Election. This is reflected in most respondents who were interested to view the Twitter and Facebook accounts owned by presidential candidates, Prabowo Subianto and Joko Widodo.

Although the political awareness of Twitter and Facebook users can be categorized as low, which is reflected by the reluctance of the youths to get involved in interactions through the accounts owned by the candidates. The reluctance of respondents neither to be a follower or friend, nor to retweet is an indication of the political awareness of young voters that is not maximized.

The second conclusion that can be drawn from the side of accounts owned by the presidential candidates is the lack of character recognition to the Twitter users. The presidential candidates appeared to be 'talkative' to use social media without taking full advantage as a medium of two-way interactive communication. However, Twitter has potential as a means for listening to the voices of constituents. From the analysis of the content of tweets posted, political parties and politicians were still packing messages that tended to be one-way and dominated to inform the activities of parties and politicians, and normal things.

The implication of both conclusions is the need to adapt in using social media, especially Twitter users' character recognition, as the majority of the users are young people that should be a primary consideration. The information needed by young people is necessary to be mapped. In addition, the characteristic recognition of Twitter is important for political parties and politicians, so that it can give a significant influence in the political process. A campaign through social media effectively influences the young voters. Listening to their friends' conversation would affect young people to make choices, and preferences of young voters.

\section{Acknowledgement}

The authors would like to express gratitude to Universitas Prof. Dr. Moestopo (Beragama), Jakarta for supporting this work.

\section{References}

[1] S. Riaz, "Effects on new media technologies on political communication", Journal of Political Studies, vol. 1, no. 2, (2010).

[2] J. Macnamara and G. Kenning, "E-electioneering 2010: Trends in social media use in Australian political communication, Media International Australia, vol. 139, (2011), pp. 7-22.

[3] O. D'Adamo, V. G. Beaudoux and T. Kievsky, "Political communication and social networks: Analysis of campaigns for legislative elections of 2013 in the city of Buenos Aires", Revista Mexicana de Opinión Pública, vol. 19, (2015), pp. 107-126.

[4] T. Faas, "Bring the state (information) in: Campaign dynamics in the run-up to a German referendum". Electoral Studies, vol. 38, (2015), pp. 226-237.

[5] M. A. Beam, M. J. Hutchensb and J. D. Hmielowskib, "Clicking vs. Sharing: The relationship between online news behaviors and political knowledge", Computers in Human Behavior, vol. 59, (2016), pp. 215-220. 
[6] A. Momoc, "New media and social media in the political communication", European Integration Realities and Perspectives Proceedings, vol. 6, (2011), pp. 556-562.

[7] M. Huberty, "Can we vote with our tweet? On the perennial difficulty of election forecasting with social media", International Journal of Forecasting, vol. 31, no. 3, (2015), pp. 992-1007.

[8] N. Pennington, K. L. Winfrey, B. R. Warner and M. W. Kearney, "Liking Obama and Romney (on Facebook): An experimental evaluation of political engagement and efficacy during the 2012 general election", Computers in Human Behavior, vol. 44, (2015), pp. 279-283.

[9] Retrievedonhttp://nasional.kompas.com/read/2013/05/29/09070488/Parpol.Serius.Garap.Media.Sosial

[10] Retrieved on http://www.marketing.co.id/prabowo-vs-jokowi-strategi-capres-di-media-sosial/

[11] Retrieved on http://www.antara.net.id/index.php/2014/01/02/pemilih-pemula-pemilu-2014-potensibesar-sosialisasi-program-yang-belum-merata/id/.

[12] Retrieved on http://tempo-institute.org/internet-viral-marketing-cara-baru-memperkenalkan-budayabangsa/

[13] McQuail, D. Mass Communication Theory. SAGE, (2000).

[14] A. M. Kaplan and M. Haenlein, "Users of the world, unite! The challenges and opportunities of Social Media", Business Horizons, vol. 53, (2010), pp. 59-68.

[15] S. J. McMillian, "Exploring Model Interactivity from Multiple Research Traditions: Users", Documents and Systems, London: Sage, (2002).

[16] L. D. Kelley, "Advertising Media Planning", A Brand Management Approach, Second Edition. M.E. Sharpe, Inc.: New York, (2008).

[17] M. Gurevitch, S. Coleman and J. G. Blumler, "Political Communication -- Old and new media relationships", The ANNALS of the American Academy of Political and Social Science, vol. 625, (2009), pp. 164-182.

[18] A. Hutchinson, "The five levels of political awareness", Retrieved on http://blogcritics.org/the-fivelevels-of-political-awareness. 